\title{
Structural analysis of composite metakaolin-based geopolymer concrete
}

\section{Análise estrutural do compósito de concreto geopolimérico à base de metacaulim}
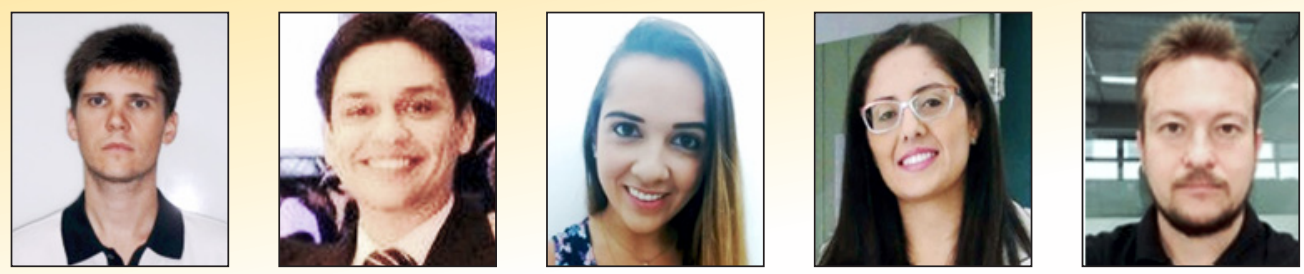

F. PELISSER a

pelisser@hotmail.com

B. V. SILVA b dovalesilva@hotmail.com

M. H. MENGER a manuela.hm@hotmail.com

B. J. FRASSON a
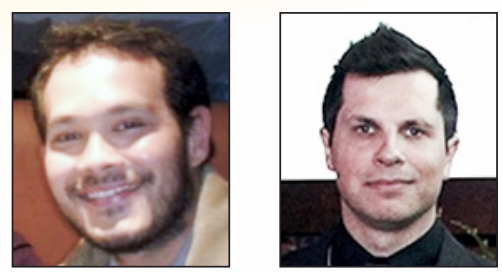

brunajfrasson@hotmail.com

T. A. KELLER

tchekeller7@hotmail.com

A. J. TORII ${ }^{d}$

ajtorii@hotmail.com

R. H. LOPEZ a

rafaelholdorf@gmail.com

\begin{abstract}
The study of alternative binders to Portland cement, such as geopolymer cements, offers the chance to develop materials with different properties. With this purpose, this study evaluated experimentally the mechanical behavior of a geopolymer concrete beam and compared to a Finite Element (FE) nonlinear numerical model. Two concrete beams were fabricated, one of Portland cement and another of metakaolin-based geopolymer cement. The beams were instrumented with linear variable differential transformers and strain gauges to measure the deformation of the concrete and steel. Values for the compressive strength of the geopolymer cement concrete was $8 \%$ higher than the Portland cement concrete (55 MPa and $51 \mathrm{MPa}$, respectively) and the tensile rupture strength was also $8 \%$ higher $(131 \mathrm{kN})$ for the geopolymer concrete beam in relation to Portland cement concrete beam $(121 \mathrm{kN})$. Distinct failure mechanisms were verified between the two samples, with an extended plastic deformation of the geopolymer concrete, revealing post-fracture toughness. The geopolymer concrete showed higher tensile strength and better adhesion in cement-steel interface.
\end{abstract}

Keywords: concrete, geopolymer, beam, finite element.

\section{Resumo}

O estudo de aglomerantes alternativos ao cimento Portland, como os cimentos geopoliméricos, contribui para o desenvolvimento de materiais com diferentes propriedades. Com este objetivo, nesta pesquisa, foi avaliado experimentalmente o comportamento de vigas de concreto comparando com modelo numérico utilizando Elementos Finitos. Foram fabricadas duas vigas de concreto, uma utilizando cimento Portland e outra utilizando cimento geopolimérico. As vigas foram instrumentadas com LVDT's e strain gauges para medir a deformação do concreto e do aço. A resistência à compressão do concreto geopolimérico foi $8 \%$ superior em relação ao concreto de cimento Portland ( $55 \mathrm{MPa}$ e $51 \mathrm{MPa}$, respectivamente) e a tensão de ruptura a flexão também foi $8 \%$ superior para a viga de concreto geopolimérico (131 kN) em relação a viga de concreto de cimento Portland (121 kN). Mecanismos distintos de ruptura foram observados, com maior deformação plástica para viga de concreto geopolimérico, mostrando sua tenacidade. O concreto geopolimérico apresentou maior resistência de aderência à tração e maior coesão na interface com a armadura.

Palavras-chave: concreto, geopolímero, viga, elementos finitos

\footnotetext{
Civil Engineering Department, Adamantinenses University, Adamantina, SP, Brazil;

Sivil Engineering Department, Adamantinenses University, Adama

Ganta Catarina Extreme South University, Criciúma, SC, Brazil;
}

Received: 15 Feb 2017 • Accepted: 04 Dec 2017 • Available Online:

This is an open-access article distributed under the terms of the Creative Commons Attribution License 


\section{Introduction}

The growing demand for concretes with higher performance, lower cost and reduced environmental impact has promoted the development of clinker-free alternative cementitious materials [1]. The use of clinker-free materials, including alkali-activated cements (AACs), also referred as 'geopolymers', can reduce the carbon footprint of construction projects when compared to those using conventional Portland cements [1, 2].

Geopolymer cements are increasingly being studied because they present improvements in certain properties compared with Portland cement, namely competitive costs and lower environmental impact [3-6]. Among the main characteristics of this cement, the following should be highlighted: excellent mechanical strength [3] and high temperature $\left(800^{\circ} \mathrm{C}\right)$ [7], long-term durability [4], low shrinkage [5], fast setting [4] and acid resistance [8]. The material can be produced using a wide variety of raw materials - do not require materials of high purity and uniformity [9]. Considering these characteristics, the development of geopolymer concretes and their application to elements with structural purpose is a promising field of research.

Numerous studies [3-9] have evaluated the compositions and materials used to produce geopolymers, their curing procedures, general mechanical properties, durability and thermal properties. Geopolymers result from a three-dimensional aluminosilicate network, composed by amorphous to semicrystalline structures [10]. Two main alkali-activated binding systems were established: (i) one composed by silica and blast furnace slag $(\mathrm{Si}+\mathrm{Ca})$, (ii) the other based on metakaolin and fly ash (Si+Al) [11]. Blast furnace slag [12], fly ash [13, 14] and metakaolin-based geopolymers [15-17] have been widely studied in the last decade, and results revealed their potential for the construction industry $[1,3]$. High compressive strength values, around $60 \mathrm{MPa}$ at 28 days $[3,18]$ and over $70 \mathrm{MPa}$ at 90 days [19], better cohesion and adhesion of the cement matrix to reinforcement elements $[3,20]$, are some of its advantageous properties.

The majority of the research papers published focus on the analysis of the micromechanical and mechanical properties of geopolymer paste/mortar/concrete. However, for the employment of geopolymer materials in the construction industry, it is of paramount importance the characterization of the structural behavior of reinforced concrete elements having them as bonding material. However, only a few studies involving the application of geopolymer cements in structural elements had been reported.
Recently, for example, Un, Sanjayan, Nicolas and Deventer [21] tested a geopolymer concrete beam having as goal the study of its cracking and deformation for the slow application of the load. These authors showed that the geopolymer concrete beam strength results are viable for the use as structural elements, however they detected cracking in the curing stage and indicated that further analysis should be pursued. Maranan et al. [22] investigated the structural performance of five GFRP- reinforced beams and compared their results to a steel-reinforced geopolymer concrete beam (the control specimen). As a result, they showed that the bending-moment capacities at concrete crushing failure of the GFRP-reinforced geopolymer concrete beams were 1.2-1.5 times greater than the one of the steel-reinforced geopolymer concrete beam with similar reinforcement ratio.

In this context and in order to contribute to the state of the art of this subject, this paper aims at evaluating the structural performance of reinforced concrete beams whose bonding component is the geopolymer cement. Also, it gives a step forward in utilization of such cement in elements with structural purpose, advancing the work developed by the authors on the characterization of the micromechanical behavior of geopolymer cement pastes/mortars [23]. The main idea here is to identify if the properties of geopolymer cement, such as ductility and tensile strength, contribute to the structural performance of beams. In order to accomplish this goal, first, the mechanical behavior of the geopolymer concrete is evaluated by pursuing compressive strength, steel-concrete bond and elastic modulus experiments. Then, a 4 point bending test is developed in order to measure the structural performance of the geopolymer reinforced concrete beam. In both cases, mechanical characterization of the concrete and of the beam, specimens are fabricated with Portland cement to serve as reference results. Finally, a non-linear finite element model of the geopolymer beam is built using the experimental data (acquired in the geopolymer concrete experiments) and its results are compared to the experimental ones.

\section{Materials and methods}

As it was mentioned in the introduction, we divide the experiments in two steps: (i) characterization of the mechanical behavior of the geopolymer concrete, and (ii) analysis of the structural behavior of reinforced geopolymer concrete beam. For the first step, it is necessary to evaluate the compressive strength, elastic modulus and steel-concrete bond, while the second phase is accomplished with a

\section{Table 1}

Composition of concretes used to produce RefBeam e GeoBeam beams

\begin{tabular}{|c|c|c|c|}
\hline Materials & GeoBeam (in mass) & Materials & RefBeam (in mass) \\
\hline Geopolymer cement 1 & 1 & Portland cement & 1 \\
\hline $\mathrm{H} 2 \mathrm{O} / \mathrm{MK}(\mathrm{g} / \mathrm{g})$ & 0.75 & w/c ratio & 0.40 \\
\hline Sand & 3.8 & Sand & 2.3 \\
\hline Gravel & 1.2 & Gravel & 2.7 \\
\hline Sand+Gravel & 5 & Sand+Gravel & 5 \\
\hline Density $\left(\mathrm{kg} / \mathrm{m}^{3}\right)$ & 2350 & Density $\left(\mathrm{kg} / \mathrm{m}^{3}\right)$ & 2360 \\
\hline
\end{tabular}




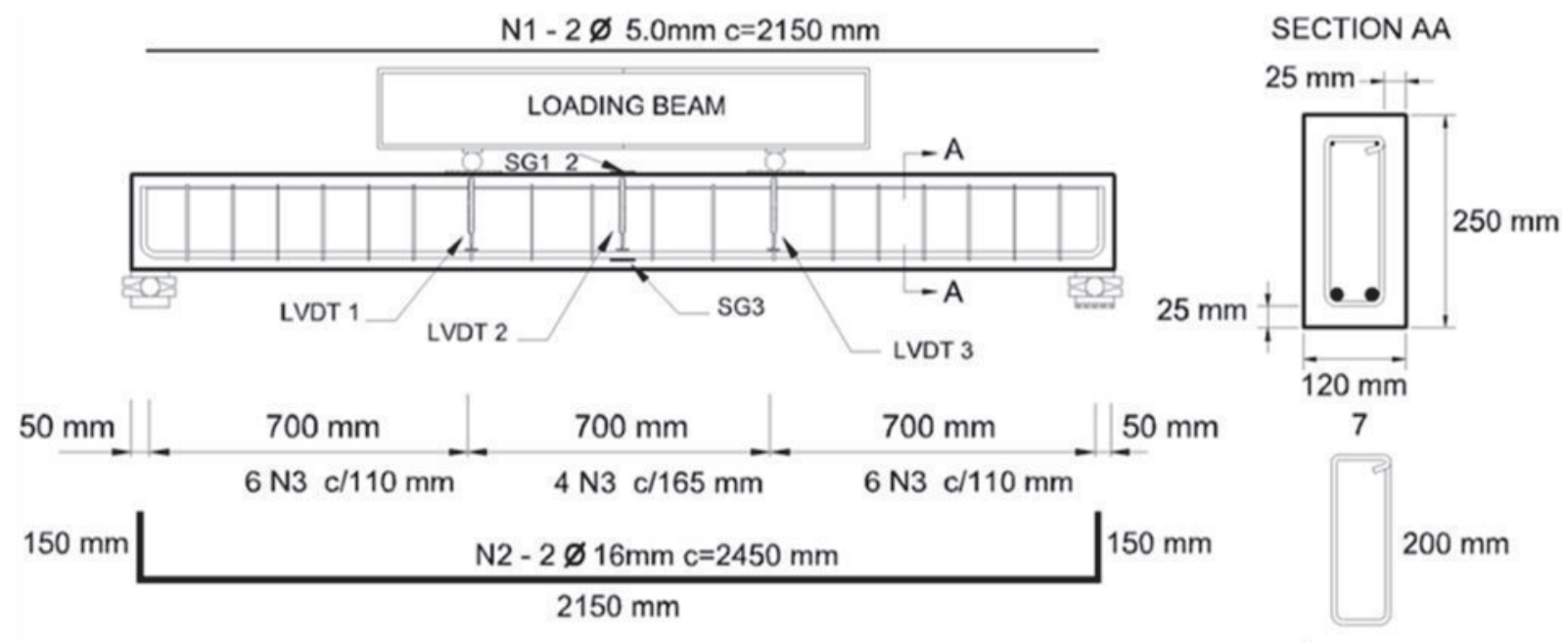

$\mathrm{N} 3-\varnothing 6.3 \mathrm{~mm} \quad \mathrm{c}=580 \mathrm{~mm}$

\section{Figure 1}

Schematic representation of bending tests performed with prepared reinforced beams

four-point beam bending test [24]. To create a basis of comparison, in both steps specimens also are fabricated with Portland cement, which are considered as reference results. In the sequence, we first define the composition of the concretes used in this research, and then, we present the details about both experimental steps.

\subsection{Concrete composition and production}

The experimental setup initiates with the data required to produce the concrete. Table 1 gives the composition of the cement and the concretes prepared to produce the specimens for the concrete mechanical characterization as well as the beams. It is important to mention that the reference concrete is produced with Portland cement (RefBeam), while the other uses geopolymer cement (GeoBeam). In both concretes, Standard sand (NBR 7215 [25]) was utilized. Such a sand is composed of equal mass fractions of four distinct sizes - 0.15-0.3 mm, 0.3-0.6 mm, 0.6-1.2 mm, and 1.2-2.4 $\mathrm{mm}$. Gravel (with a fineness modulus of 4.67 and a maximum diameter of $12.5 \mathrm{~mm}$ ) was also added.

Cement mixing was performed in a $10 \mathrm{~L}$ mixer, followed by the addition of the aggregates, and an additional mixing step (in a $20 \mathrm{~L}$

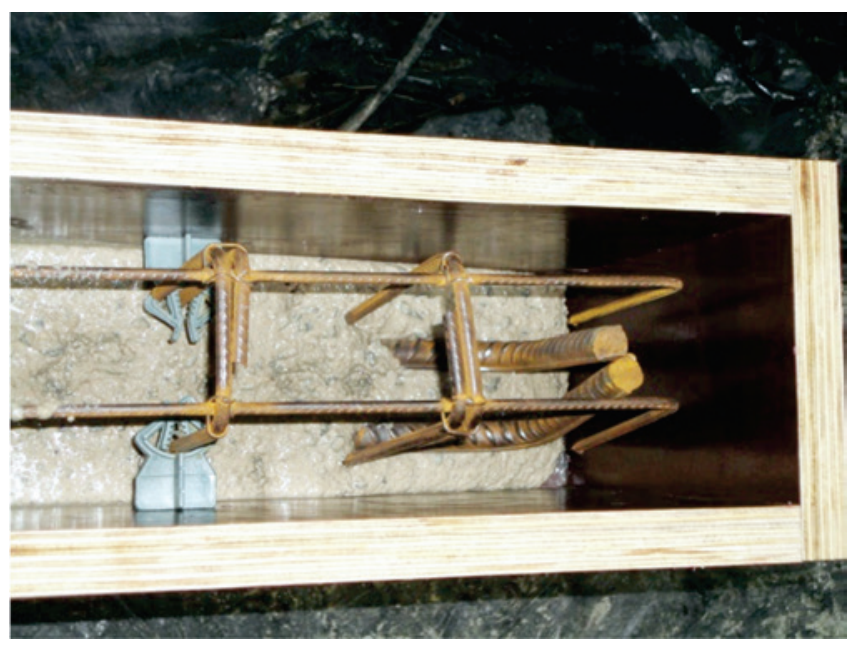

Figure 2

Application of Geopolymer concrete in the beam mixer). Cylindrical test specimens measuring $10 \times 20 \mathrm{~cm} \varnothing$ were molded for the compressive strength and elastic modulus tests, while for the steel-concrete bond tests, test samples measuring 10 $x 10 \mathrm{~cm} \varnothing$ were produced.

\subsection{Concrete mechanical characterization}

The compressive strength determination was evaluated in an electric-hydraulic testing machine, with a $0.5 \mathrm{MPa} / \mathrm{s}$ loading rate [26], at curing age of 7,21 and 28 days. The elastic modulus was determined using the stress/strain curve obtained in the compressive strength test. The elastic modulus was determined by the tangent of the stress-strain curve, for values up to $0.5 \mathrm{MPa}$ [27].

Steel-concrete bond was measured by push-in tests [28]. Ribbed steel rods were used with a nominal diameter $(\varnothing)$ of $8.0 \mathrm{~mm}$ and anchor length $40.0 \mathrm{~mm}(5 \varnothing)$. The steel yield strength is $597 \mathrm{MPa}$ and the ultimate stress is $747 \mathrm{MPa}$, both obtained from a tensile test at a controlled speed, according to the parameters ISO 68921:2009 [29]. Two linear variable differential transformers (LVDTs) were positioned on the opposite sides of each test sample to control the relative displacement of the compressed rod in relation to the concrete. The bond strength test was performed in an electrichydraulic testing machine, with a $0.032 \mathrm{MPa} / \mathrm{s}$ loading rate, as recommended by RILEM RC6:1983 [30]. The maximum bond stress (Tb, max) was calculated using equation 1 :

$\tau_{b, \text { máx }}=\frac{F_{\text {máx }}}{\pi \cdot \emptyset \cdot l_{\text {exp }}}$

where $F_{\text {max }}$ is the maximum load achieved during testing, $\varnothing$ is the diameter of the steel rod and $l_{\text {exp }}$ is the length of the experimental anchorage.

\subsection{Structural behavior of the beams}

The behavior of the geopolymer concrete within a structural element was evaluated using the four-point bending test [24], which is schematically illustrated in Fig. 1. A part of the actual beam is shown in Fig. 2.

The Portland and geopolymer concrete beams tested in this research have the same dimensions - $12 \times 25 \times 220 \mathrm{~cm}$ (width $x$ height $x$ length) - and reinforcement $-16 \mathrm{~mm}$ and 

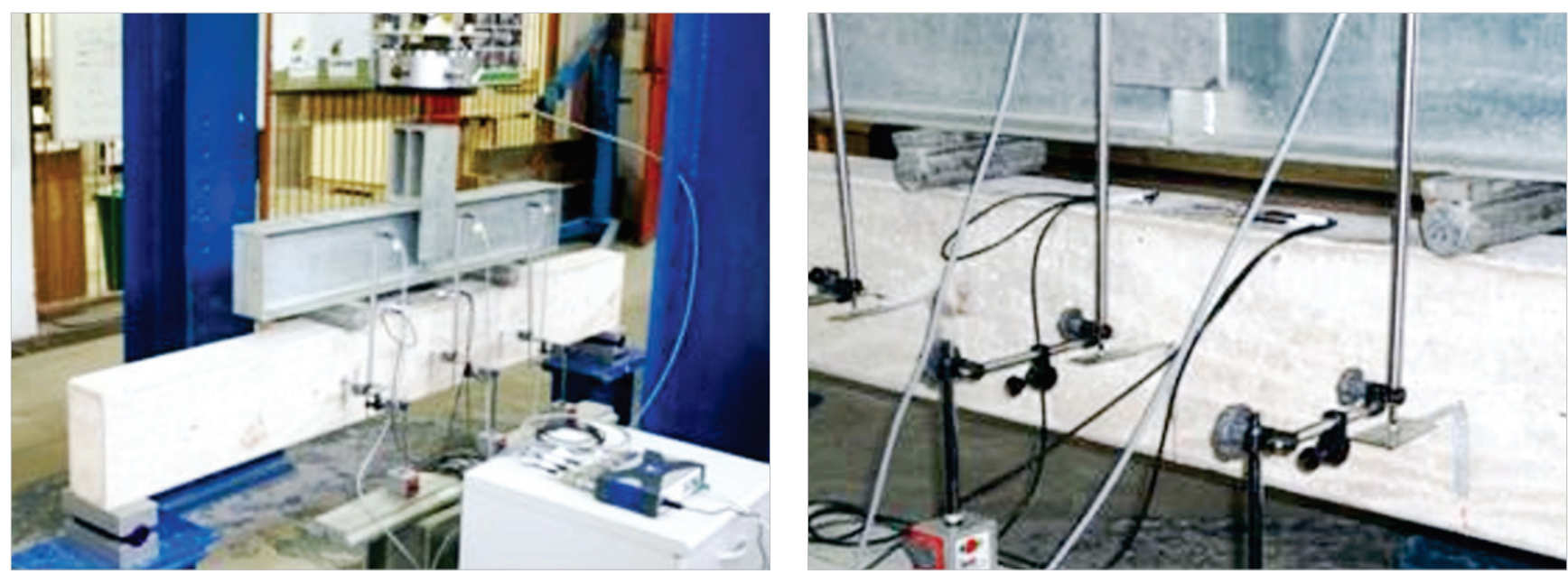

\section{Figure 3}

(a) Setup experimental of Geopolymer concrete beam gauges in Geopolymer concrete beam

$5 \mathrm{~mm} \varnothing$ steel rods were utilized (Fig. 1). The beams were project according to requirements of NBR 6118 [24], i.e. ductile structures. Both concrete beams were cured in ambient, with relative humidity around $60 \%$ and temperature of $23 \pm 2{ }^{\circ} \mathrm{C}$.

The strain gauges were fixed on the steel bars (SG3, Fig 1) at the mid-span of the beam. Two other strain gauges were fixed on the concrete compression cover (SG1 and SG2 - Fig. 1 and 3).

The overall ductility $\mu_{d}$ of the beam is calculated by equation 2 :

$\mu_{d}=\frac{\delta_{u}}{\delta_{y}}$

where $\delta_{u}$ is the maximum displacement at failure and $\delta_{y}$ is the maximum displacement at yield stress (to reach the plastic region - plastic load).

The correlation between the applied load and the " $\varphi$ " curvature formed in the cross-section of the beam, which takes into account the specific deformations measured by the strain gauges (SG) in the steel (SG-T) and in the concrete (SG-C) is given by the equation 3:

$\phi=\frac{\varepsilon_{s}-\varepsilon_{c}}{d}$

where $\varphi$ is the curvature of the cross-section, $\varepsilon_{\mathrm{s}}$ is the deformation of the steel, $\varepsilon_{c}$ is the deformation of the concrete in the most compressed fiber of the cross-section, and $d$ is the distance from extreme compression fiber to centroid of longitudinal tension reinforcement.

\section{Results and discussion}

\subsection{Mechanical properties of concrete}

The compressive strength of the geopolymer cement concrete was $8 \%$ higher than Portland cement concrete (28 days), achieving 55 $\mathrm{MPa}$ and $51 \mathrm{MPa}$, respectively (Table 2). However, the rate of strength gain of Portland cement concrete was higher than that of geopolymer concrete in the first curing period (up to 7 days), probably because the curing of geopolymer concrete was performed at room temperature (and not as usual thermal curing). The mean value of the elastic modulus of the geopolymer concrete was estimated as $26 \mathrm{GPa}$, which is very similar to previous results obtained for the same type of metakaolin-based geopolymer mortar [20]. This value is about $45 \%$ lower than the one estimated for the Portland cement concrete ( $48 \mathrm{GPa})$. This rigidity loss or increase in deformation is characteristic of geopolymer concretes [31] and it has influence of the $\mathrm{Si} / \mathrm{Al}$ ratio. Low ratio of $\mathrm{Si} / \mathrm{Al}<3$ result in three dimensional cross-linked rigid network, whereas a higher ratio of Si/Al>3 results in two dimensional network having linearly linked

\section{Table 2}

Measured mechanical properties of the two concretes

\begin{tabular}{|c|c|c|c|c|c|}
\hline \multirow{2}{*}{$\begin{array}{c}\text { Geopolymer } \\
\text { concrete }\end{array}$} & \multicolumn{3}{|c|}{ Compressive strength (MPa) } & $\begin{array}{c}\text { Elastic modulus } \\
\text { (GPa) }\end{array}$ & $\begin{array}{c}\text { Bond strength } \\
\text { (MPa) }\end{array}$ \\
\cline { 2 - 6 } & $\mathbf{7}$ days & $\mathbf{2 1}$ days & $\mathbf{2 8}$ days & $26.1 \pm 0.2$ & $34.1 \pm 0.3$ \\
\hline Mean (s.d.) & $5.4 \pm 0.2$ & $44.5 \pm 5.4$ & $55.1 \pm 2.2$ & & 3 \\
\hline
\end{tabular}

\begin{tabular}{|c|c|c|c|c|c|}
\hline \multirow{2}{*}{$\begin{array}{c}\text { Portland } \\
\text { concrete }\end{array}$} & \multicolumn{3}{|c|}{ Compressive strength (MPa) } & $\begin{array}{c}\text { Elastic modulus } \\
\text { (GPa) }\end{array}$ & $\begin{array}{c}\text { Bond strength } \\
\text { (MPa) }\end{array}$ \\
\cline { 2 - 6 } & $\mathbf{7}$ days & $\mathbf{2 1}$ days & $\mathbf{2 8 ~ d a y s}$ & $48.1 \pm 1.4$ & $26.1 \pm 1.0$ \\
\hline Mean (s.d.) & $33.5 \pm 0.6$ & $49.1 \pm 1.6$ & $50.6 \pm 1.4$ & \\
\hline
\end{tabular}




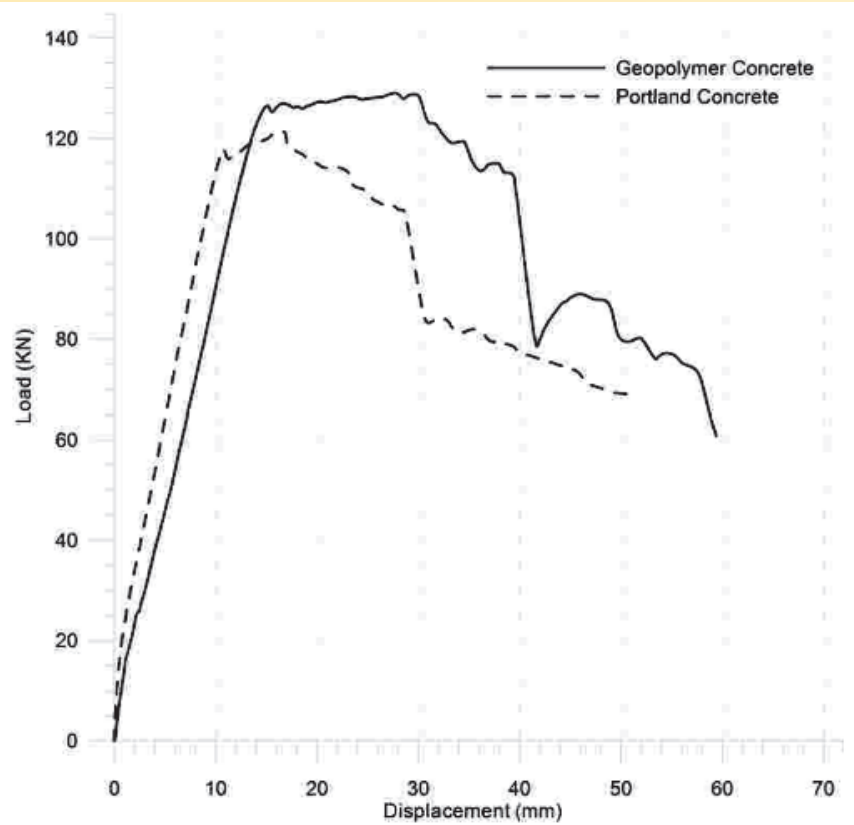

Figure 4

Load vs vertical displacement curves of the tested beams, obtained by using the LVDTs

polymeric structures [32]. In this work the molar ratio $\mathrm{Si} / \mathrm{Al}=3.2$ (table1), being between the two zones.

In the steel-concrete bond test, the displacement of the steel rod as a function of the applied load was measured and the bond strength results are in Table 2. The steel rod slippage in the geopolymer concrete was $40 \%$ lower than in Portland cement concrete, while the maximum bond stress was $23 \%$ higher. All the test samples showed slipping of the steel rod in relation to the concrete and no apparent concrete cracking was observed. The higher value of steel-concrete bond stress obtained in the geopolymer concrete contributes to the decrease in the anchoring length of the reinforced concrete beams. This shorter anchoring length will contribute to structural elements with lower steel consumption per cubic meter of concrete. This fact can generate structural elements more economical in comparison to the Portland cement concrete.

\subsection{Structural behavior of the beams}

Figure 4 shows loading vs. displacement curves of the beams for both concretes. GeoBeam showed a maximum failure load of $131.7 \mathrm{kN}$ (maximum bending moment, $\mathrm{Mu}=48.9 \mathrm{kN} . \mathrm{m}$ ), while the Refbeam reached $121.4 \mathrm{kN}(\mathrm{Mu}=45.1 \mathrm{kN} . \mathrm{m})$. The cracking loads were estimated as $17.1 \mathrm{kN}$ (cracking bending moment, $\mathrm{Mcr}=6.9$ $\mathrm{kN} . \mathrm{m})$ and $20.4 \mathrm{kN}(\mathrm{Mcr}=8.1 \mathrm{kN} . \mathrm{m})$, respectively, for the GeoBeam and RefBeam. The maximum displacement at service load (L/250, NBR 6118) [22] was $77.7 \mathrm{kN}$ (Moment at L/250 - M(L/250) $=29.1 \mathrm{kN} . \mathrm{m}$ ) for the GeoBeam, while it was equal to $98.9 \mathrm{kN}$ $(\mathrm{M}(\mathrm{L} / 250)=36.9 \mathrm{kN} . \mathrm{m})$ for the RefBeam.

The plasticity load was $127.0 \mathrm{kN}$ (plasticity moment, $\mathrm{Mp}=47.2$ kN.m) and $116.2 \mathrm{kN}(\mathrm{Mp}=43.2 \mathrm{kN} . \mathrm{m})$ for the GeoBeam and RefBeam, respectively. It is important to highlight here that the failure load was $8 \%$ greater for the geopolymer concrete beam. The maximum displacement at failure load was equal to $27.6 \mathrm{~mm}$, while for plasticity load was $14.4 \mathrm{~mm}$, which results in an overall ductility factor of 1.92 for the GeoBeam. For the RefBeam, the maximum displacement at failure load was $16.5 \mathrm{~mm}$ and for plasticity load was $10.4 \mathrm{~mm}$, which results in an overall ductility factor of 1.59 .

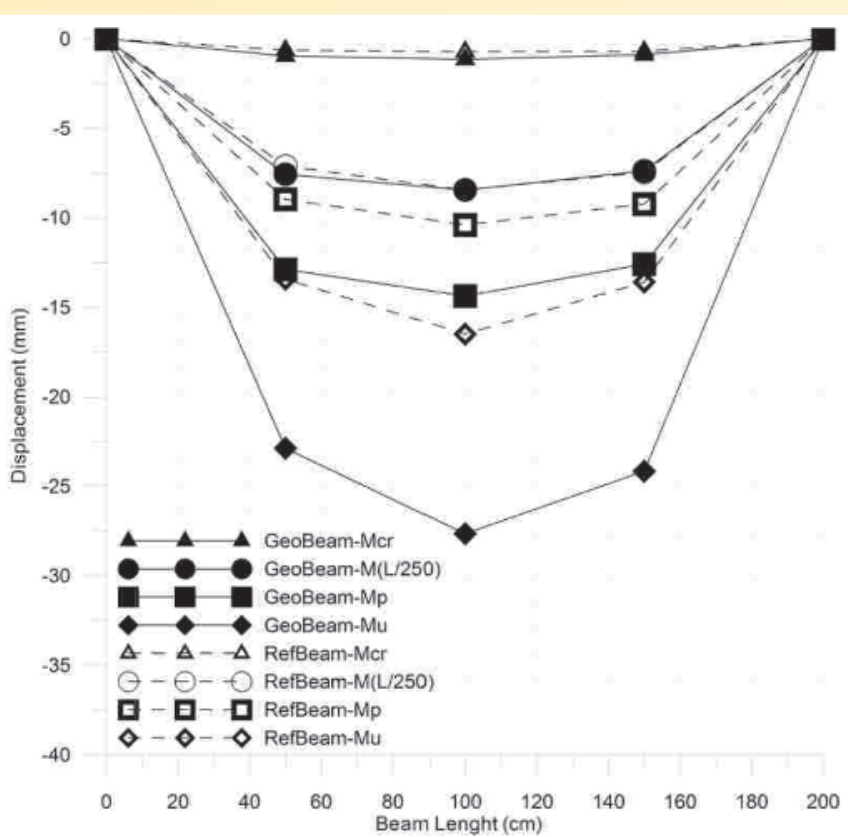

Figure 5

Vertical displacement along the beams length, measured by the LVDTs during the loading test

Figure 5 shows the elastic line obtained by using the three LVDTs. Taken together, these results revealed that the GeoBeam presents higher plastic deformation (see Fig. 4), leading to higher ductility. This behavior has been observed by other researchers when evaluating the ductility of geopolymer cement composites with fibers [31]. The geopolymer concrete can support higher deformation without failure since it shows higher resistance to crack propagation or higher tenacity. This is revealed for the GeoBeam in the plastic regime (Fig. 4). Despite less rigid than Refbeam, differences in the elastic regime are not very high, i.e. similar behavior in the elastic regime.

Figure 6 presents the specific deformation of the steel (measured

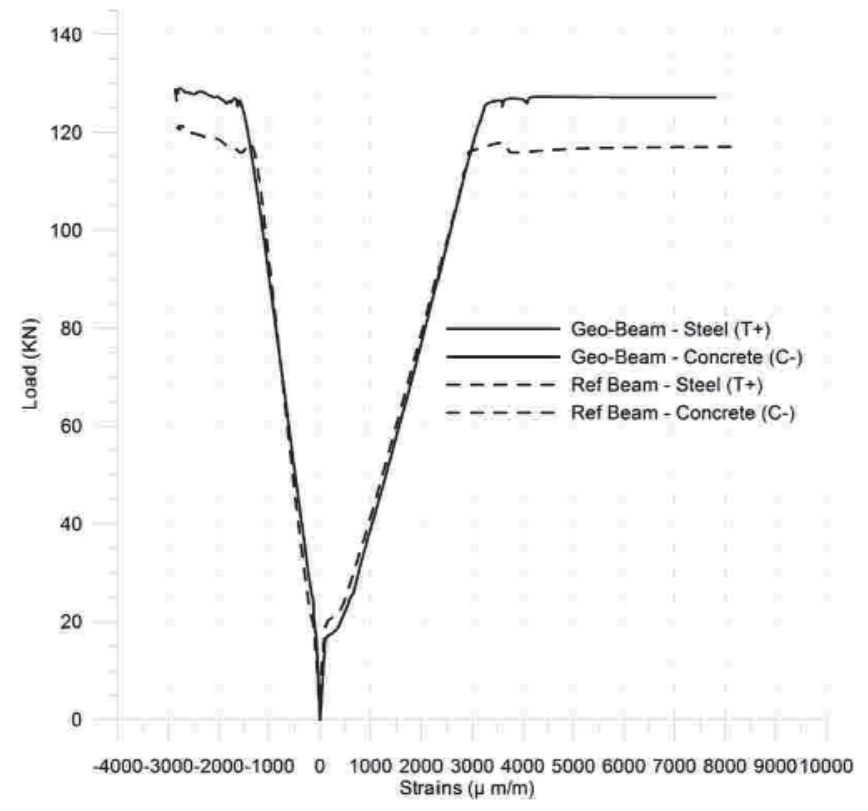

\section{Figure 6}

Separated load vs deformation curves of the steel and concrete components of the two beams 


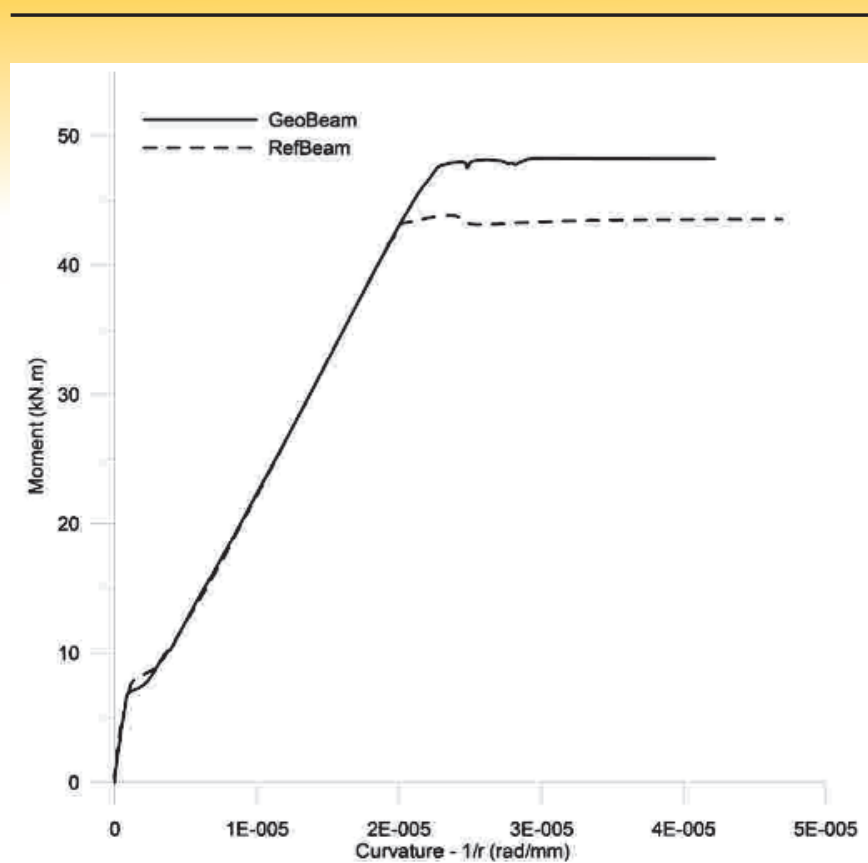

\section{Figure 7}

Moment vs curvature curves measured for the tested beams

at the base of the beam) and of the concrete (evaluated on the top of the beam), upon loading in the flexural tensile mode. The deformation at maximum load is rather similar for the two concretes: geopolymer $=2.77 \%$; Portland cement $=2.78 \%$. This is another evidence of the suitability of the geopolymer concrete as a substitute of Portland concrete for selected structural applications. Complementarily, the curvatures " $\phi$ " of the beams, measured upon charging until the plasticity loads were equal to $2.02 \times 10^{-5} \mathrm{rad} / \mathrm{mm}$ and $2.28 \times 10^{-5} \mathrm{rad} / \mathrm{mm}$ for the RefBeam and GeoBeam, respectively (Fig. 7), which shows a rotation capacity higher than $11 \%$ for the GeoBeam before the plasticity moment compared with the RefBeam. Figure (8a) and (8b) shows the behavior of the beams with respect to cracking after rupture, showing a small decrease of the cracking for the geopolymer concrete.

In general, the mechanical behavior of the geopolymer concrete makes it a potential candidate to be applied to structural elements. This concrete has higher bond on steel-concrete interface, ductility and toughness, which improved the structural performance of the beam when compared to the Portland cement concrete beam. Another research demonstrate that fly ash-based geopolymer concrete has excellent potential for applications in the precast industry [33]. Therefore, there is a great potential for geopolymer concrete to be cast in situ [34]. However, more experimental tests, involving numerous variables that influence the execution of structures, so that this material can be used safely.

\subsection{Analysis using Finite Element Method (FEM)}

The experimental results were also compared to a Finite Element (FE) nonlinear numerical model, presented in Figure 9. Because of symmetry, only half structure is studied. Both geometrical and physical nonlinearities were taken into account. The steel bars and the concrete were modeled using quadratic truss elements and quadratic plane stress elements, respectively. The support was modeled using a $75 \mathrm{~cm}$ length zone composed by rough contact elements, which prevent horizontal slippage, and an elastic basis (the material of the support was assumed elastic since we are not interested in the plastic
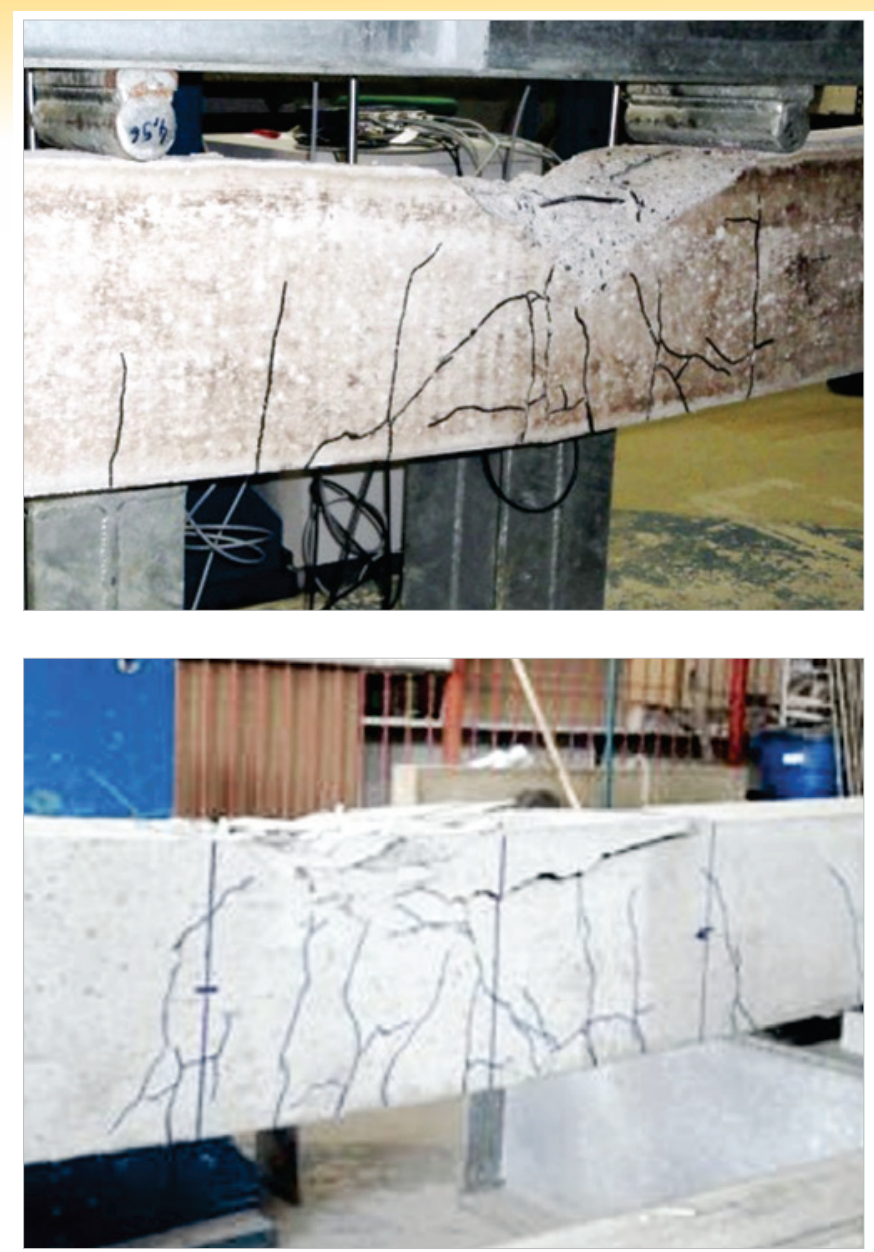

\section{Figure 8}

State of the beams after the experiments. (a) Geopolymer concrete (b) Portland concrete

response of this part of the structure). The load was applied in a $10 \mathrm{~cm}$ length zone in order to prevent stress concentrations. Besides, perfect bond between steel bars and the concrete is assumed (this assumption was observed accurate enough in this case). The properties of the steel and the concrete were the ones obtained in the mechanical characterization experiments. Constitutive behavior of the steel assumes that yielding occurs at $597 \mathrm{MPa}$ and the ultimate stress is $747 \mathrm{MPa}$. Constitutive behavior of the concrete is made using a smeared crack model. The necessary parameters that were not measured in this work (e.g. concrete response in tension, Poisson's coefficient) were

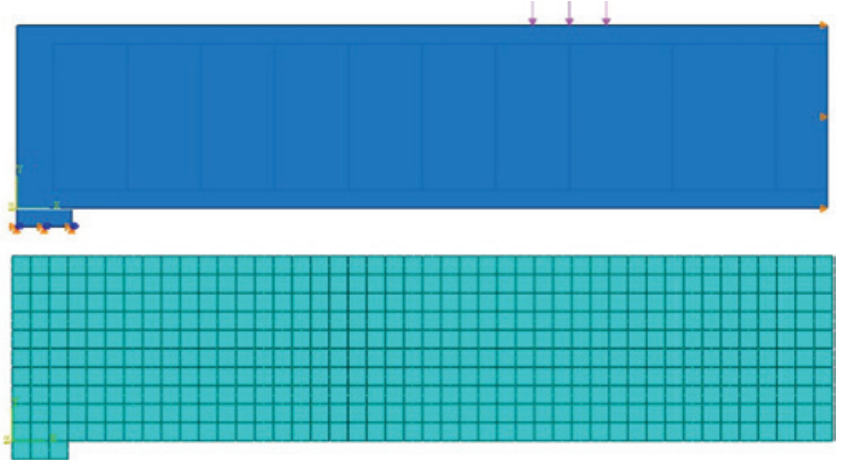

\section{Figure 9}

Numerical model 

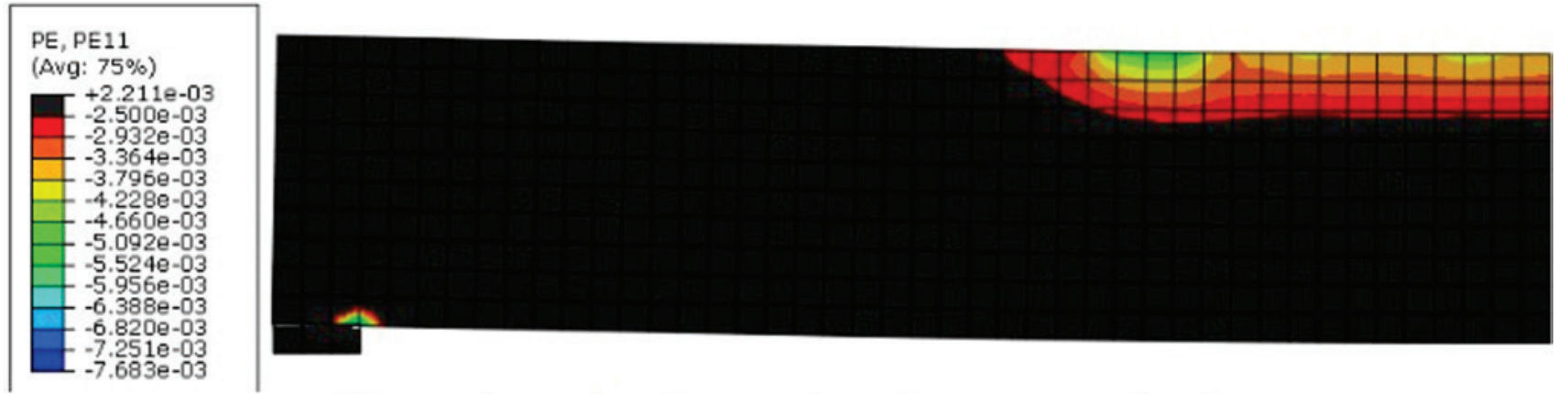

\section{Negative plastic strains (compressive)}
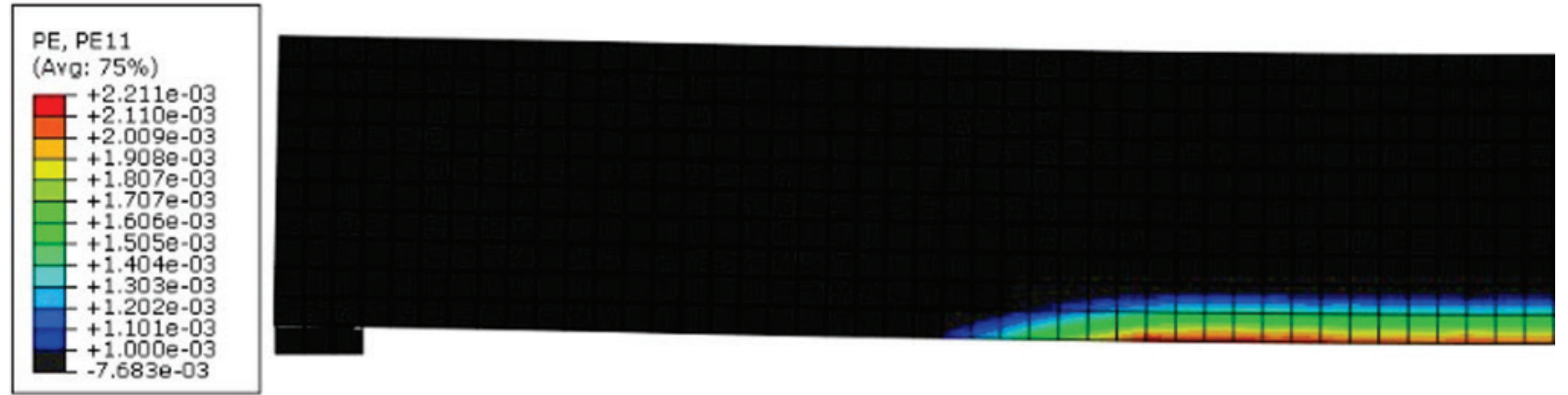

\section{Positive plastic strains (tensile)}

\section{Figure 10}

Longitudinal plastic strains

taken as standard values presented by [35]. The positive (tensile) and negative (compressive) longitudinal plastic strains are presented in Figure 10. We note that the lower part of the structure presents tensile plastic strains, while the upper part and a small region close to the support present compressive plastic strains. These results agree with experiments (see Figure 8a), since the concrete was crushed in the upper part of the beam (compressed beyond its resistance). The deflection at mid-span is presented in Figure 11. The ultimate resistance obtained $(136.5 \mathrm{kN})$ and the deflection response obtained also indicate an agreement between the experiments and the numerical model.

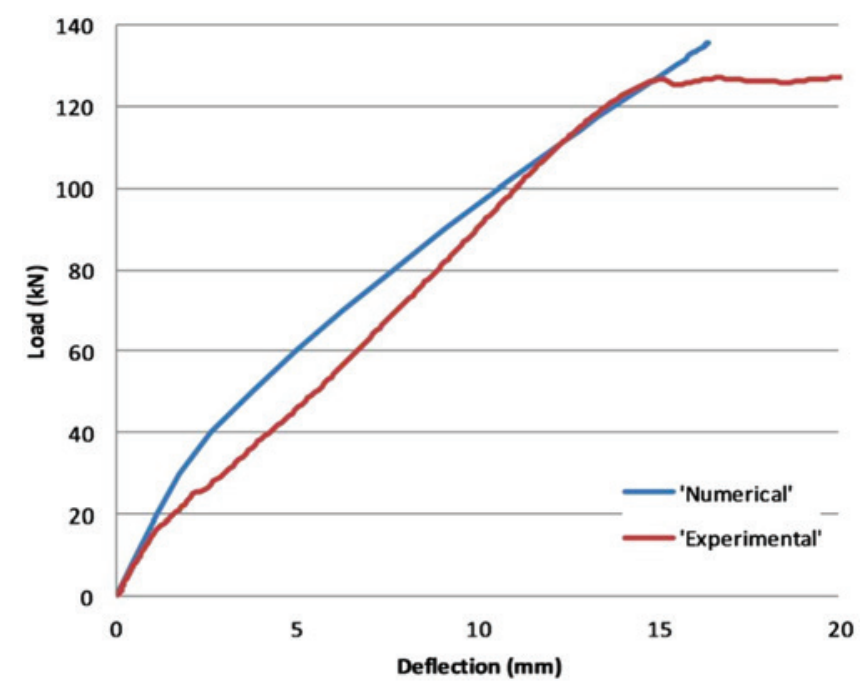

Figure 11

Deflection at mid-span of Geopolymer concrete beam

\section{Conclusions}

This research analyzed the structural behavior of a geopolymer concrete beam and compared its results to a cement Portland beam. This analysis began with the characterization of the mechanical behavior of the geopolymer concrete. Then, the structural analysis of the beam with different bonding materials was investigated by a 4 point bending test. Finally, a non-linear finite element model of the geopolymer beam was built using the experimental data acquired in the geopolymer concrete experiments and its results were compared to the experimental ones.

The characterization of the mechanical properties of the geopolymer concrete showed that it has better steel-to-concrete bonding, higher compressive strength at 28 days and lower rigidity than the Portland concrete. The main results of the analysis of the structural behavior were:

- the geopolymer concrete beam is more ductile: ductility coefficient of 1.92 of the GeoBeam, while the Refbeam was 1.59;

- the geopolymer concrete beam reached higher maximum failure load and plasticity load than the Portland concrete structure;

- the geopolymer concrete beam presented higher toughness than the conventional structure.

The finite element model generated with the data from the mechanical characterization of the geopolymer concrete presented reasonable results since the numerical results agreed with the experimental ones.

From the experimental tests carried out on two prototype beams, it was possible to show the potential of the geopolymer concrete for application in structures. The tested beam - more than two years old - is exposed to the external environment, with no signs of leaching or other deterioration. Also, two more beams were tested, in reduced scale, resulting in the same behavior. Despite all manufacturing limitations for applying geopolymer concrete, it is a 
material with promising performance, which uses low cost raw materials and industrial waste.

Acknowledgements

The authors gratefully acknowledge the Conselho Nacional de Desenvolvimento Científico e Tecnológico (CNPq) for providing the financial support for this research (grant number 443573/2014-0 and 302268/2016-2).

\section{References}

[1] J.L. Provis, A. Palomo, C. Shi, Advances in understanding alkali-activated materials, Cement and Concrete Research 78 (2015) 110-125.

[2] M.C.G. Juenger, F. Winnefeld, J.L. Provis, J. Ideker, Advances in alternative cementitious binders, Cem Concr Res. 41 (2011) 1232-1243.

[3] A. Rashad, Alkali-activated metakaolin: A short guide for civil Engineer - An overview, Construction and Building Materials 41 (2013) 751-765.

[4] K. Komnitsas, D. Zaharaki, Geopolymerisation: a review and prospects for the minerals industry, Miner Eng. 20 (2007) 1261-1277.

[5] P. Duxson, Geopolymer technology: the current state of the art, J Mater Sci. 42 (2007) 2917-2933.

[6] M. Ozel, Cost analysis for optimum thicknesses and environmental impacts of different insulation materials, Energy and Buildings 49 (2012) 552-559.

[7] Z. Pan, J.G. Sanjayan, B.V. Rangan, An investigation of the mechanisms for strength gain or loss of geopolymer mortar after exposure to elevated temperature, Journal of Materials Science 44 (2009) 1873-1880.

[8] F. Pacheco-Torgal, Z. Abdollahnejad, A.F. Camões, M. Jamshidi, Y. Ding, Durability of alkali-activated binders: A clear advantage over Portland cement or an unproven issue?, Construction and Building Materials 30 (2012) 400-405.

[9] R. Chen, S. Ahmari, L. Zhang, Utilization of sweet sorghum fiber to reinforce fly ash-based geopolymer, Journal of Materials Science 49 (2014) 2548-2558.

[10] J. Davidovits, Geopolymers: inorganic polymeric new materials, J Therm Anal. 37 (1991) 1633-1656.

[11] A. Palomo, M. Grutzek, M. Blanco, Alkali-activated fly ashes: A cement for the future, Cement and Concrete Research 29 (1999) 1323-1331.

[12] J.E. Oh, P.J.M. Monteiro, S.S. Jun, S. Choi, S.M. Clark, The evolution of strength and crystalline phases for alkali-activated ground blast furnace slag and fly ash-based geopolymers, Cement and Concrete Research 40 (2010) 189-196.

[13] S.K. Nath, S. Kumar, Influence of iron making slags on strength and microstructure of fly ash geopolymer, Construction and Building Materials 38 (2013) 924-930.

[14] P. Sukmak, S. Horpibulsuk, S-L. Shen, Strength development in clay-fly ash geopolymer, Construction and Building Materials 40 (2013) 566-574.

[15] V. Zivica, S. Balkovic, M. Drabik, Properties of metakaolin geopolymer hardened paste prepared by high-pressure compaction, Construction and Building Materials 25 (2011) 2206-2213.
[16] C. Li, H. Sun, L. Li, A review: The comparison between alkaliactivated slag $(\mathrm{Si}+\mathrm{Ca})$ and metakaolin $(\mathrm{Si}+\mathrm{Al})$ cements, $\mathrm{Ce}-$ ment and Concrete Research 40 (2010) 1341-1349.

[17] I. García-Lodeiro, A. Fernándes-Jiménez, A. Palomo, Alkaliactivated based concrete. In: F. Pacheco-Torgal, S. Jalali, J.A. Labrincha, V.M. John, editors. Eco-efficient concrete. UK: Woodhead Publishing Limited (2013) p. 26-41.

[18] X. Guo, H. Shi, W.A. Dick, Compressive strength and microstructural characteristics of class $\mathrm{C}$ fly ash geopolymer. Cement \& Concrete Composites 32 (2010) 142-147.

[19] S. Songpiriyakij, T. Kubprasit, C. Jaturapitakkul, P. Chindaprasirt, Compressive strength and degree of reaction of biomass- and fly ash-based geopolymer, Construction and Building Materials 24 (2010) 236-240.

[20] T-H Ueng, S.-J Lyu, H.-W Chu, H.-H Lee, T-T Wang, Adhesion at interface of geopolymer and cement mortar under compression: An experimental study. Construction and Building Materials 35 (2012) 204-210.

[21] C.H. Un, J.G. Sanjayan, R. San Nicolas, J.S.J. van Deventer, Predictions of long-term deflection of geopolymer concrete beams, Construction and Building Materials 94 (2015) 10-19.

[22] G.B. Maranan, A.C. Manalo, B. Benmokrane, W. Karunasena, P. Mendis, Evaluation of the flexural strength and serviceability of geopolymer concrete beams reinforced with glass-fibre-reinforced polymer (GFRP) bars, Engineering Structures 101 (2015) 529-541.

[23] F. Pelisser, E.L. Guerrino, M. Menger, M.D. Michel, J.A. Labrincha, Micromechanical characterization of metakaolinbased geopolymers, Construction and Building Materials 49 (2013) 547-553.

[24] NBR 6118 (2014). Project of Concrete Structures; Brazilian Association of Technical Standards: Rio de Janeiro, Brazil. (in Portuguese)

[25] NBR 7215 (1997). Portland cement: Compressive strength; Brazilian Association of Technical Standards: Rio de Janeiro, Brazil. (in Portuguese)

[26] ASTM C-1231 (2010). Standard practice for use of unbonded caps in determination of compressive strength of hardened concrete cylinders. ASTM International, West Conshohocken, PA, USA.

[27] NBR 8522 (2017). Concrete - Determination of elastic modulus and the stress-strain curve; Brazilian Association of Technical Standards: Rio de Janeiro, Brazil. (in Portuguese)

[28] B.V. Silva, Proposal of an bond test for the technological control of the compressive strength of concrete, Ph.D. Thesis (Civil Engineering), Federal University of Rio Grande do Sul, Porto Alegre, Brazil, 2014. (in Portuguese)

[29] International Organization for Standardization. ISO 6892-1 (2009). Metallic materials - Tensile testing - Part 1: Method of test at room temperature.

[30] COMITÉ EURO-INTERNATIONAL DU BÉTON. RILEM/ CEB/FIP RC6 (1983). Bond test for reinforcing steel - 1 pull-out test. Paris: CEB.

[31] B. Nematollahi, J. Sanjayan, F.U.A. Shaikh, Comparative deflection hardening behavior of short fiber reinforced geopolymer composites. Construction and Building Materials 70 (2014) 54-64. 
[32] M. S. Reddy, P. Dinakar, B. Hanumantha Rao, A review of the influence of source material's oxide composition on the compressive strength of geopolymer concrete, Microporous and Mesoporous Materials 234 (2016) 12-23.

[33] D. Sumajouw, D. Hardjito, S. Wallah, B. Rangan, Fly ashbased geopolymer concrete: study of slender reinforced columns, Journal of Materials Science 42 (2007) 3124-3130.

[34] M. Reed, W. Lokuge, W. Karunasena, Fibre-reinforced geopolymer concrete with ambient curing for in situ applications, Journal of Materials Science 49 (2014) 4297-4304.

[35] W.F. Chen, Plasticity in Reinforced Concrete, McGraw-Hill, New York, 1982. 